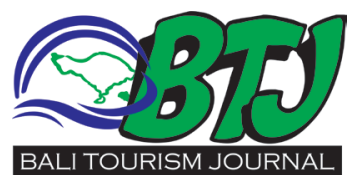

\section{Palelindon: Unravel the hidden meaning of earthquake}

\author{
Ida Bagus Agung Wicaksana ${ }^{1}$
}

\title{
ABSTRACT
}

On the history of humanity, multiple approaches and methods have been conducted to determine reliable formula on predicting when and where the earth would release its seismic pulse. Many quests have been conducted for more than century to forecast the quake occurrence, yet failed to meet the expectation for long run prediction. Earthquake in a simple term is defined as convulsion on the earth's surface. Based on its trigger, the quake could be classified into two namely seismic activity and tremor. A vast horseshoe area covers $40,000 \mathrm{~km}$ square in the shore of pacific ocean is notorious for its title as The Ring of fire (ROF); an area that has been experiencing continuous series of lithosphere seismic activities. Living within the geologically active area, Bali as part of Indonesia since ancient times seemed to experience multiple quakes. While most research relentlessly sought to predict the earthquake accurately, Balinese local wisdom claimed to be ably predicting the aftereffect of earthquake as compiled in Palelindon manuscript. The script proposed detailed explanation of earthquake effect on nature that subsequently affects human behaviour. This idea may seem as old myth, and could not be suggested publicly worldwide as scientific explanation. Balinese life is firmly bound by local belief and custom. Nevertheless, the text explanation occasionally is taken into account as precaution to prepare any upcoming upheaval on the island.
${ }^{1}$ Agung Property Construction aqunqwicaksana12@gmail.com

\section{Editor:}

Ida Bagus Ngurah Tri Pramana

\section{INTRODUCTION}

On the history of humanity, multiple approaches and methods have been conducted to determine reliable formula on predicting when and where the earth would release its seismic pulse. Geller (1997) pointed out that many quests have been conducted for more than century to forecast the quake occurrence, yet failed to meet the expectation for long run prediction. ${ }^{1}$ Since its occurrence is highly unpredictable, by far, disaster mitigation drill seems to be the most effective plan to minimise the number of victims. The drill then developed into a complex system. In Japan, Japan meteorological agency established earthquake early warning system. ${ }^{2}$ It acts as alarming system, but only to warn neighbour epicentre area of any potential upcoming wave after the quake occurs. However, with technology advancement, there is a hope that perhaps one day the disaster precursor would be accurately detectable.

\section{EARTHQUAKE IN BRIEF}

Earthquake in a simple term is defined as convulsion on the earth's surface. Based on its trigger, the quake could be classified into two namely seismic activity and tremor. ${ }^{3}$ Seismic activity is a result of lithosphere movements that gradually take place overtimes.
Sometimes it could release low rumbling waves that unable to be felt by the human, or violent shock wave that could crumble the building in matter of second. In 1935, Charles F. Richter proposed a measurement scale which known as Richter's magnitude scale, later revised as Local magnitude scale. ${ }^{4}$ The scale is determined from recorded amplitude of waves logarithm by seismographs. The magnitude of the earthquake is ranging from 1 to 10, as described in Figure 1.

A tremor is considered a condition where ground shaking as a result of human activities. It may result from explosive agents that generate enough power to tremble the earth; shockwave on meteorite impact or any activity that does not emerge from the earth.

\section{THE RING OF FIRE}

A vast horseshoe area covers $40,000 \mathrm{~km}$ square in the shore of pacific ocean is notorious for its title as The Ring of fire (ROF). Firstly discovered in the $19^{\text {th }}$ century as an area that has been experiencing continuous series of lithosphere seismic activities; approximately 90 per cent of the earthquake on the globe occurred in this area including the most significant quakes in history of planet earth. Sometimes, the quakes also trigger huge oceanic waves tsunami, which multiplies its destructive 


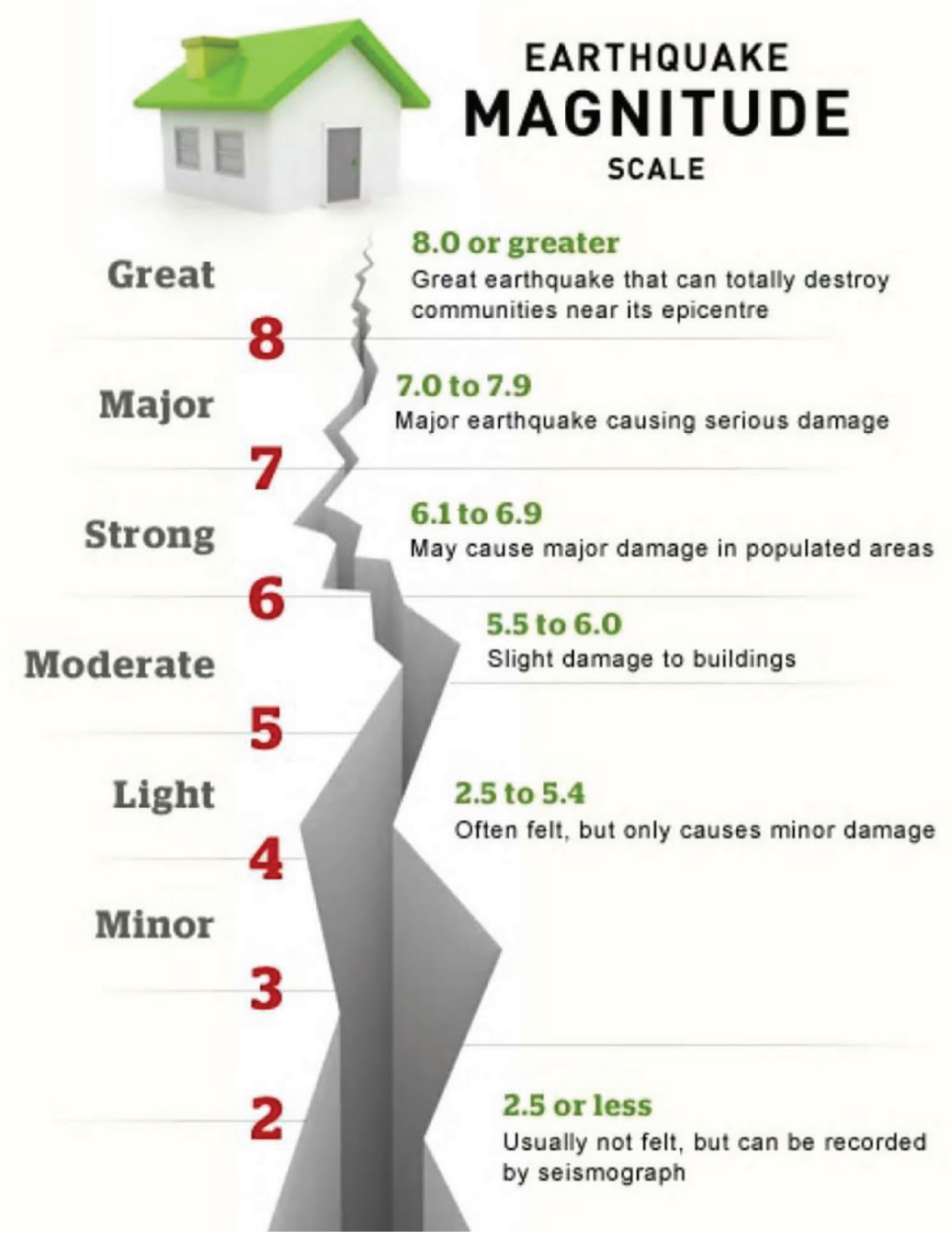

Figure 1. Richter 'magnitude' scale

effect on land. The movement and collisions of earth plates over aeons have been resulting the ROF established. Today, the ROF consists of 452 active volcanoes, volcanic belts as well as volcanic arcs and oceanic trenches as result of earth's faults. ${ }^{6}$

The ROF stretches from the western coast of South America; northward to North America then westward through Aleutian islands, Russia's Kamchatka peninsula, Japan, southward to Philippine, then westward through Indonesia archipelago, turning eastward to the Kermadec - Tonga arcs and New Zealand as its endpoint. Galapagos and Hawaiian islands are some areas that lie within the ROF that considered as geologically active regions. ${ }^{7}$ In Indonesia extends numerous highly active volcanoes such as Kelud, Merapi and Sinabung. Also, some prominent eruptions recorded in history were lake Toba supervolcanic eruption that approximately erupted in $74.000 \mathrm{BP}$, Tambora in 1815 , and Krakatoa in 1883. Those eruptions were known for their global impact. Tambora eruption caused the year without summer; it heavily damaged crops in some parts of Europe, united states and Canada. Worse effects resulted by Toba supervolcano, which brought volcanic winter for six years. The quake magnitude is incomparable to modern era seismic waves. ${ }^{8}$

\section{EARTHQUAKE IN BALI}

Living within the geologically active area, Bali as part of Indonesia since ancient times seemed to experience multiple quakes that resulted from lithosphere or tectonic movements due to its position within the ROF and active volcanoes on the island. For instance, When the plate experiences movement or volcanic events take place, Balinese would loudly chant 'Idup...Idup....Idup...' while finding an open space until the shaking vanishes. In fact, according to local beliefs, they viewed two giant dragons; Basuki and Ananthaboga are creatures that responsible in generating the seismic pulses as a result of their action in binding a massive turtles Bedawang as the earth's base. ${ }^{10}$ Every time those creatures move, then it would create disturbances to the surface of the earth; thus, an earthquake occurs. Today, this idea is outdated and no longer served as chief explanation of question why the ground is rumbling by Balinese. They prefer to find clarity through scientific explanation or report, though elders may occasionally bring up the myth in their informal chattering.

However, Bali geographic condition does not mean as a complete disadvantage. The island is blessed by fertile land and lushed exotic green scenery, thanks to Mountain Agung, Batur and Batu Karu; three active volcanoes that exist on the island of God. Mount Agung is considered as the centre of religious activity and called the mother mountain. ${ }^{11}$ Realized about the common disaster on island, Balinese forefather took great precautions about their offspring safety. They proposed a series of texts; compiled from their experiences about general phenomena in Bali, such as ritual, medication, or even disaster mitigation as manual to face the upcoming event. Architectural texts Asta Kosala kosali and Asta Bumi, for instances, propose clear do and don't guidance in establishing a building on the island. ${ }^{12}$ The local wisdom suggests one should build a residence or temple based on their needs, owner's physical size, and precisive spatial distance thus the building would be stable, and resistant to disasters that commonly occur in Bali including the earthquake. $^{13}$ 


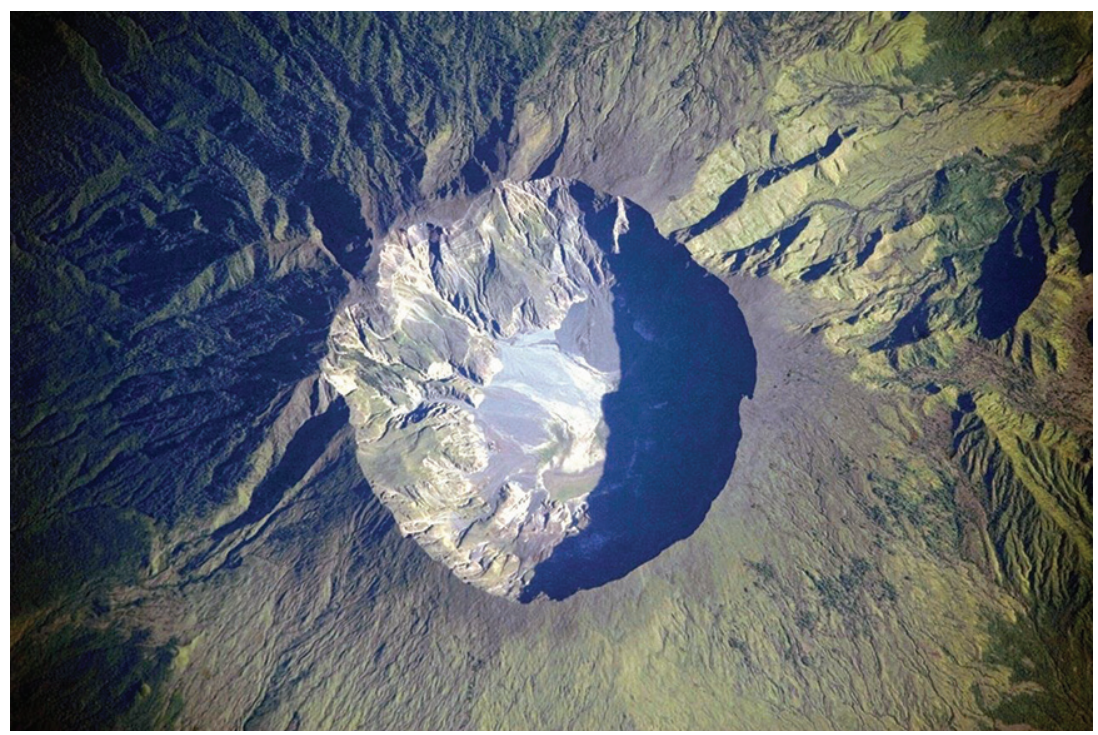

Figure 2. Mount Tambora. In 1815, Its eruption caused the year without summer; it heavily damaged crops in some parts of Europe, united states and Canada. ${ }^{9}$

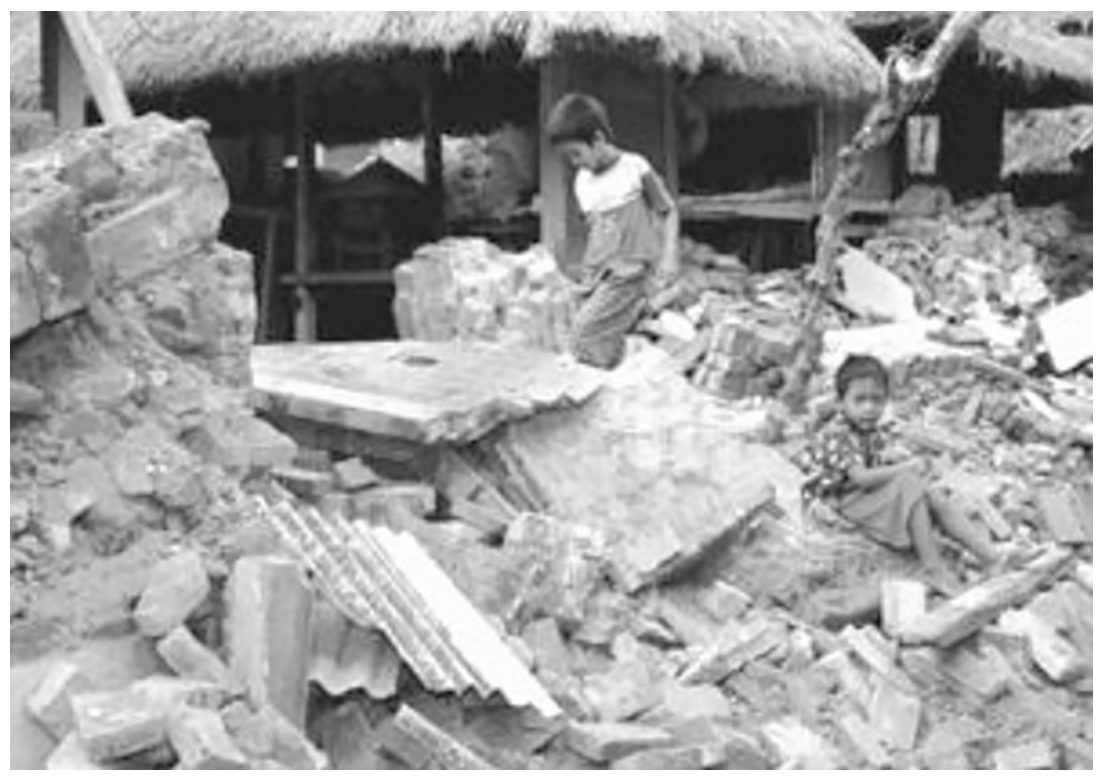

Figure 3. Rubbles of Seririt Earthquake ${ }^{14}$

The notable earth activities that occurred in Bali in the $19^{\text {th }}$ century was Seririt earthquake. Seririt quakes or well known in local tongue as 'Gejer Bali; was a 6.2 magnitude earthquake, with its epicentre located on the land. The quake took tolls of 559 lives, 850 heavily injured, and 3200 lightly injured. The report estimated $75 \%$ building in Tabanan and Jembrana were lightly damage while the epicentre in Seririt, no building survived the disaster.

The aghast truth was discovered later. Most of the victims survived the quake because of the building frame when crumbling, it stacked precisely to make the triangle of life; thus, it created enough safety space to take cover of any avalanche from above. The architecture highly depended on wood frame and pillars, with leaves, clay tiles or stacked bamboos as the roof. Therefore when the seismic pulses took place, it did not create significant amount of massive rubble avalanche that might harm the occupant. The nature of wood frame and pillar when the seismic activities occur are adaptable to the shake. It would graciously sway to small quake, subsequently create enough time to escape when high magnitude quake hits as the building would slowly collapse. ${ }^{13}$

\section{PREDICTION OF FATE}

Although no one has ever determined the exact formula to forecast earthquake, however, In ancient Balinese text 'Palelindon', it proposes series of predictions about what would happen if an earthquake occurs on specific Sasih or month in Balinese calendar on nature and social condition. For instance, if an earthquake takes place in anytime on Sasih Karo (the $2^{\text {nd }}$ month in Balinese calendar) would result in political upheaval uncertainty, as well as the people would no longer put faith on their leader. On the other hand, it is believed rain would fall thus resulted in flourishes harvest, with occasional strong wind on land. ${ }^{15}$ Similar to any old Balinese teaching, it is no longer being taught as general knowledge or explanation. However, in conducting religious ritual, the people would still undoubtedly consult the text for attaining wisdom from their ancestors to determine correct action in handling the upcoming event.

\section{CONCLUSION}

The procedure to accurately determine time and space of the upcoming earthquake may yet have not been found. However, by far, human has been able to identify highly potential area on the planet where the quakes rumble for many decades. Moreover, they develop precaution warning system as well as the drill to escape the disaster. While most research relentlessly sought to predict the earthquake accurately, Balinese local wisdom claimed to be ably predicting the aftereffect of earthquake as compiled in Palelindon manuscript. The script proposed detailed explanation of earthquake effect on nature that subsequently affects human behaviour. This idea may seem as old myth, and could not be suggested publicly worldwide as scientific explanation. Balinese life is firmly bound by local belief and custom. Nevertheless, the text explanation occasionally is taken into account as precaution to prepare any upcoming upheaval on the island. 


\section{REFERENCES:}

1. Geller RJ. Earthquake prediction: a critical review. Geophysical Journal International. 1997 Dec 1;131(3):42550.

2. What is the Earthquake Early Warning. Japan Meteorological Agency. 2007. Available at URL: http:// www.jma.go.jp/jma/en/Activities/eew1.html

3. Buku Saku Tanggap tangkas tangguh Menghadapi Bencana Edisi 2012. Badan nasional penanganan Bencana (BNPB). 2012. Available at URL: https://bnpb.go.id/uploads/ migration/pubs/478.pdf

4. Richter CF. An instrumental earthquake magnitude scale Bulletin of the Seismological Society of America. 1935 Jan 1;25(1):1-32.

5. Image by Upseis/Michigan Tech Retrieved from CBC 'Richter 'magnitude' scale explained. CBC. 2012. Available at URL: https://www.cbc.ca/news/world/richtermagnitude-scale-explained-1.1130841

6. Hinga BD. Ring of Fire: An Encyclopedia of the Pacific Rim's Earthquakes, Tsunamis, and Volcanoes: An Encyclopedia of the Pacific Rim's Earthquakes, Tsunamis, and Volcanoes. ABC-CLIO; 2015 Mar 17.

7. N Chavez. Why Indonesia has so many earthquakes. CNN. 2018. Available At URL: https://www.cnn.com/2018/09/29/ asia/earthquakes-indonesia-explainer/index.html

8. Luterbacher J, Pfister C. The year without a summer. Nature Geoscience. 2015 Mar 31;8(4):246.

9. Image by the NASA Expedition 20 crew. - Image and and English description: Mount Tambora Volcano, Sumbawa Island, Indonesia, NASA Earth Observatory. 2nd version:
Transferred from de.wikipedia to Commons.; originally from https://eol.jsc.nasa.gov/SearchPhotos/photo. pl? mission $=I S S 020 \&$ roll $=E \&$ frame $=06563$

10. Paramadhyaksa IN. Representasi Gambaran Alam pada Perwujudan Arsitektur Padmasana di Bali. Bumi Lestari Journal of Environment. 2013;12(2).

11. Mudana IG, Sutama IK, Widhari CI. Local Community Entrepreneurship in Mount Agung Trekking. InJournal of Physics: Conference Series 2018 Jan (Vol. 953, No. 1, p. 012107). IOP Publishing.

12. Bidja IM. Asta kosala-kosali, asta bumi. Pustaka Bali Post; 2012.

13. Wicaksana IB. The art of space and architecture; Asta Kosala Kosali and Asta Bumi. Bali Tourism Journal. 2018 Aug 15;2(1):14-8.

14. Tigapuluh Sembilan Tahun Gempa Bumi Seririt. Dewata News. 2015. Available at URL: https://www.dewatanews. com/2015/07/tigapuluh-sembilan-tahun-gempa-bumi. html

15. Bhatari Gangga Mayoga, Pemimpin Pun Bimbang. Nusa Bali. 2018. Available at URL: https://www.nusabali.com/ berita/35480/bhatari-gangga-mayoga-pemimpin-punbimbang

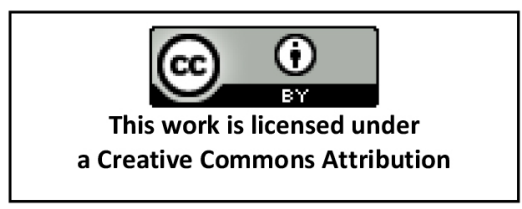

